\title{
The role of internal branding in the delivery of employee brand promise
}

Received (in revised form): 5th June, 2007

\section{KHANYAPUSS PUNJAISRI}

is Doctoral Researcher at the University of Strathclyde Business School. Her research focuses on service branding with a particular interest in corporate brands and internal branding.

\section{ALAN WILSON}

is Professor of Marketing at the University of Strathclyde Business School and Deputy Head of the Marketing Department. Prior to joining the University of Strathclyde, he held high-level positions within leading London-based marketing research agencies and a management consultancy practice. He has written numerous articles on corporate culture and reputation and has received a number of awards for his publications. He is a member of the Governing Council of the Market Research Society and is on the editorial boards of a number of leading journals. His textbook, Marketing Research:An Integrated Approach is in its second edition. He regularly acts as a marketing and market research advisor to a number of public and private organisations.

\section{Keywords}

internal branding;

customer-facing employees; brand promise delivery; corporate marketing

\section{Abstract}

In branding literature, the employee role is recognised as crucial in delivering the service as promised by the brand. A plethora of existing insights have been gained through practitioners' and customers' perspectives. Little empirical research has been undertaken with employees. Therefore, this study aims to reveal their perceptions towards their role and the techniques that enable them to fulfil the brand promise. A case-study approach is adopted using a mixture of qualitative and quantitative methodologies. In-depth interviews reveal that employees feel that their actions are vital to the brand, and findings from a survey of 699 respondents demonstrate positive relationships among internal branding instruments and their brand promise delivery. These tools influence the employees' brand attitudes, namely brand identification, brand commitment and brand loyalty. Ultimately, these attitudes also influence the manner in which employees deliver the service. Therefore, internal branding not only directly influences the extent to which employees perform their role in relation to the brand promise, but also influences the attitudes employees have towards the brand, which in turn affects employee performance. Journal of Brand Management (2007) 0, 000-000. doi:10.1057/palgrave.bm.2550110

\section{INTRODUCTION}

The rise of corporate marketing and corporate branding has raised awareness of the crucial role that employees play in corporate marketing and the corporate branding process. The historical analysis of corporate-level constructs since the 1950 s by Balmer ${ }^{1}$ reveals a number of concepts such as corporate image, corporate identity, corporate branding and corporate reputation. All these different corporate-level perspectives and concepts are synthesised under the 'corporate marketing vortex'. 2 The corporate marketing mix of Balmer as shown in Figure 1 outlines how the aforementioned concepts can possibly be orchestrated. Table 1 also gives a brief summary of each element of the corporate 
CHARACTER

(Corporate Identity)

CULTURE

(Organisational identity)

"What we feel we are"

$$
\text { "What we indubitably are" }
$$

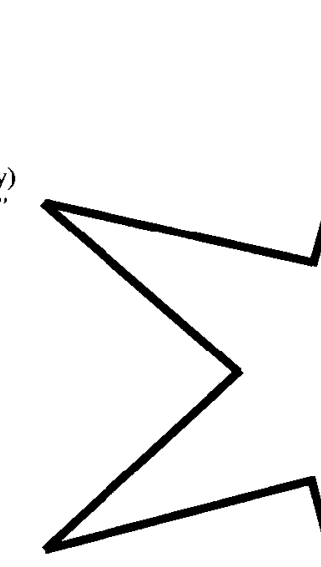

CONCEPTUALISATIONS

(Corporate reputation)

"What we are seen to be"

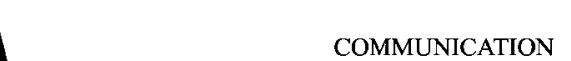

(Corporate communications) "What we say we are"

Figure I Six elements of Balmer's corporate marketing mix

Source: see Balmer's corporate marketing mix in Balmer and Greyser ${ }^{2}$ (p. 735)

Table I Explanation of the $6 \mathrm{Cs}$ of corporate marketing $\mathrm{mix}^{2}$

\begin{tabular}{ll}
\hline Corporate marketing mix & Explanation \\
\hline Character & $\begin{array}{l}\text { The factors (ie tangible and intangible assets of the organisation, } \\
\text { organisational activities, markets served, corporate ownership and } \\
\text { structure, organisational type, corporate philosophy and corporate } \\
\text { history) that make the organisation distinctive from another. }\end{array}$ \\
Employees' collective feeling (ie values, beliefs and assumptions) \\
about the organisation. \\
The various outbound communications channels (including \\
employee behaviour, word of mouth and media/competitor \\
communication & $\begin{array}{l}\text { customers and other constituencies. } \\
\text { The perceptions that customers and other key stakeholder groups } \\
\text { hold of the corporate brand. } \\
\text { Corporate marketing needs to meet the wants and needs of } \\
\text { Customers as well as other stakeholder groups. }\end{array}$ \\
Constituencies & An informal contract that underpins a corporate brand. \\
\hline
\end{tabular}

marketing mix. The focus of this paper is on the 'covenant' element of the six corporate marketing mix elements. Covenant looks at corporate marketing from the perspective of corporate branding.
As corporate branding is about multiple stakeholders interacting with the organisation's employees, its success largely relies on employees' attitudes and behaviours in delivering the brand promise to external 
stakeholders. ${ }^{3}$ To be recognised as highperforming rather than mediocre, firms have to understand and orchestrate their employees. Under this light, internal branding has emerged as a key process to align the behaviours of employees with the brand values. ${ }^{4,5}$

Despite the growing interest in internal branding, there has been limited research conducted into the processes required to encourage brand-supporting behaviour. ${ }^{6}$ Moreover, paradoxical to the need to understand employees, the existing insights have generally stemmed from research with management, brand practitioners' and even customers' perspectives. Therefore, this paper aims to unearth the perceptions of the employees who deliver brand values to the customer. It does this through undertaking multiple case studies in 4- and 5-star hotels in Thailand to reveal customerfacing employees' perceptions regarding their role in corporate marketing through the delivery of the brand promise. To help management to orchestrate their employees, the study further assesses the key tools in the internal branding process that employees consider relevant and influential to their brand attitudes and brand performance.

\section{EMPLOYEES: THE COMPANY'S MOST TENUOUS AND VULNERABLE ASSET}

The increased competition in services industries has resulted in many companies focusing on corporate marketing and building a strong corporate brand to gain competitive advantage. ${ }^{7,8}$ Whether the positioning of their corporate brand is successful remains dependent on the employees' behaviours in producing and delivering the service. ${ }^{9}$ As such, service corporations have begun to realise the importance of encouraging their employees to enact the key characteristics of the corporate service brand. Branding, however, does not immediately allow service organisations to surpass the disadvantages intrinsic in their characteristics. Service organisations remain vulnerable to variability because of their reliance on their employees.

Being at the interface of the internal and the external world of the brand, customer-facing employees exert a certain degree of influence on customers' and other stakeholders' perceptions about the brand and/or the organisation, ${ }^{10}$ which determines the success of brand positioning. ${ }^{9}$ Their distinctive skills can create a company's competitive advantage that may be difficult to be matched. ${ }^{11}$ Such a differential advantage reduces the risk of being perceived as commodities. ${ }^{12}$ However, 'as much as the human factor is the company's most tenuous competitive feature, it can also be the most vulnerable one'. ${ }^{13}$ That is, they are as much a valuable asset as they are a challenge to a service organisation. This is because people are heterogeneous. During the service delivery process, customers have to interact with different service providers, whose attitudes and behaviour may vary from one to another. This is an issue as one of the three themes identified as critical to the successful service brand is consistency. ${ }^{14}$ Thus, employees who are responsible for fulfilling the brand promise ${ }^{15}$ are required to deliver the service in a consistent manner to attain and maintain the desired identity, a coherent corporate image, ${ }^{16}$ and a corporate reputation. ${ }^{17}$

To ensure that employees behave in ways that support the brand promise, internal branding has become of great importance to academia and practitioners.

\section{INTERNAL BRANDING}

Internal branding is considered as a means to create powerful corporate brands. It 
assists the organisation in aligning its internal process and corporate culture with those of the brand. ${ }^{18-21}$ Management and brand consultants have been key figures in providing valuable insights to the concept of internal branding. Little research has, however, been devoted to exploring the perceptions of the employees. As the concept underlines the role of services employees, their views may be important if management is to implement the most appropriate internal branding programmes. This paper focuses on the perceptions of employees at the interface between the organisation and customers. Rather than focusing on what internal branding and internal marketing (IM) means to the participants, the present paper attempts to answer what methods should be applied based on employees' perceptions of relevance.

The objective of internal branding is to ensure that employees transform espoused brand messages into brand reality for customers and other stakeholders. A number of publications have identified that successful internal branding engenders employees' commitment to, ${ }^{22}$ identification with ${ }^{22}$ and loyalty to $^{23}$ the brand. When employees internalise the brand values, they will consistently deliver on the brand promise across all contact points between the company and its stakeholders. ${ }^{16}$ To implement successful internal brand building, IM has been suggested as a key instrument. Although IM is regarded as an appropriate approach for communicating the brand internally,communication is not the sole method to ensure the success of the internal branding campaign. Machtiger $^{24}$ remarked that one of the six pitfalls in internal branding is to rely largely on internal communications (ICs). In fact, internal branding requires a broader integrative framework across corporate marketing, corporate management and corporate human resource management. Marketing functions as a link between communication, service and quality. Both service and quality could in part be enhanced by understanding techniques used by the HR function, as it is involved in developing the human asset to enhance the organisation's economic performance ${ }^{25}$ and its brand's success. ${ }^{26}$ If management can understand and orchestrate marketing and HR theories, it is argued that employees will better accept and internalise the brand values and align their attitudes and behaviour, accordingly. ${ }^{16,27}$ This will result in the brand promise being delivered to the organisation's clients, providing it with customer satisfaction, customer preference and loyalty. ${ }^{28}$

ICs aim to influence employees' brand knowledge, attitudes and behaviours. The outcomes of ICs include employee commitment, shared vision, a serviceminded approach, loyalty and satisfaction. ${ }^{29}$ While ICs operate with the current members inside the organisation, the role of the HR department begins with selecting and recruiting the right prospects. With the rise of the concept of 'person-organisation fit', de Chernatony ${ }^{4,30}$ underlines the value congruence between the candidates, the organisations and the brand. As values are hard to change, staff recruitment based on the level of value congruence is sometimes more viable than emphasising merely on their technical/operational skills. Then, training and development programmes are essential to enhance employee performance and to bring consistency to the external brand experience. Therefore, HR should be led by marketing and incorporate the brand concept ${ }^{31}$ into all employee development programmes. To maintain brand standards, an organisation should reward employees accordingly. ${ }^{32}$ Effective reward and recognition schemes can enhance employee motivation and 
commitment. When the right employees are kept satisfied, the organisation tends to retain the best people facilitating superior performance. ${ }^{33}$ Therefore, incorporating the wisdom from HR practitioners, ICs move beyond merely distributing brand information through media towards creating shared brand understanding.

Although a number of publications have addressed how to implement a successful internal branding process, most of these insights have been acquired from a management's and brand consultant's perspective. Few studies have been done to unearth the perceptions of employees who are considered as the 'internal customers'. Therefore, the overall aim of the paper is to assess the key instruments in internal branding required to engender employees' on-brand behaviours. It will also determine the role of employees' attitudes in the process of internal brand building to ensure consistent brand promise delivery.

\section{RESEARCH METHODOLOGY}

To address this aim, a case-study approach was selected with a mix of qualitative and quantitative research. First, the qualitative research was performed, utilising semistructured interviews with senior managers and customer-interface employees in six major Thai hotels. The qualitative research led to the development of the quantitative phase of the research with customer-interface employees. The research instruments were tied in with the findings from the literature review for external validity and for rigorous analysis. ${ }^{34}$ Undertaking the literature review, a programme of qualitative research and a programme of quantitative research created a form of data triangulation overcoming any shortcomings of the case-study research, such as a lack of rigour. ${ }^{35}$
The selection of hotels was based on their quality standards signified by stars. 4- and 5-star hotels were selected as it was felt that they would make efforts to protect their corporate brand and reputation. Moreover, they were likely to have an adequate number of customer-interface employees for the quantitative phase. Finally, due to their location, the hotels provided international-level services to international customers. As they operate in a multinational market, this should counter against the criticism of examining so-called Western philosophy in a nonWestern (Thailand) context. Apart from hotel selection, key informants needed to be identified. As argued by Vallaster and de Chernatony, ${ }^{16}$ leaders or senior management are key drivers that support internal brand building particularly in an international environment. As such, it was felt that people at a senior level had the best overview of the internal branding programmes in the organisation. To gain access to these senior bodies, the General Manager or Vice President of each hotel was contacted and informed about the research. Due to the nature of the research focus, they suggested that the interviews be undertaken with directors from HR, Food and Beverage (F\&B), Front Office $(\mathrm{F} / \mathrm{O})$ and Housekeeping departments. Then, the directors assigned one or two customer-interface employees from three departments (F\&B, F/O, and Housekeeping) for an interview. In total, 20 senior and middle management and 30 customer-facing employees were involved in the in-depth interviews, each of which lasted one to one hour and a half. All interviews were taped and transcribed to reduce the risk of observer bias. ${ }^{36}$ Content analysis was applied to analyse the data. Following Miles and Huberman's ${ }^{37}$ framework, the transcripts were produced and studied several times to identify common 
themes and statements as appeared in the interviews. This led to the generation of notes in a matrix format, which identified the constructs along one axis and the respondents' statements on the other.

The quantitative research was necessary to measure the identified constructs and clarify the links between them. ${ }^{38} \mathrm{~A}$ survey with customer-facing employees was conducted. Questionnaires were posted to the hotels participating in the first stage. One out of six hotels was unable to grant access. The qualitative findings, however, suggested no major differences between that hotel and the other five hotels. Employees from three departments, namely F\&B, F/O and housekeeping $(n=747)$ participated in the survey by taking a questionnaire prior to their shift. To guard against social desirability behaviour, respondents were assured by their leaders that their answers would remain anonymous and genuine answers were necessary to improve internal branding initiatives. Of the 747 questionnaires handed out, 699 individuals completed the survey giving a response rate of 94 per cent.

The questionnaire used a 5-point Likert scale as it is one of the most common ways of measuring attitudes. ${ }^{39}$ The measurement items were selected based on previous empirical research ${ }^{37-43}$ and verified thorough extensive discussion in the qualitative interviews to fulfil the face validity of predictor scales. ${ }^{44}$ To assess the internal consistency of the scales used in the present research, Cronbach alpha reliability coefficients were calculated for each predictor item. Reliability estimates ranged from 0.71 to 0.87 (Table 2). Because reliability values between 0.6 and 0.8 are generally considered sufficient for research purposes, ${ }^{45}$ the scales used in this study can be regarded relatively reliable.
Table 2 Reliability coefficients (Cronbach alpha) for scales used in the research

\begin{tabular}{ll}
\hline Scale & $\begin{array}{l}\text { Reliability } \\
\text { coefficient }(\boldsymbol{\alpha})\end{array}$ \\
\hline Internal communication & 0.79 \\
Training & 0.8 \\
Brand performance & 0.81 \\
Brand identification & 0.87 \\
Brand commitment & 0.78 \\
\hline
\end{tabular}

\section{RESEARCH FINDINGS AND ANALYSIS}

The perceptions of management and employees are in agreement regarding the crucial role of customer-facing employees in fulfilling the brand promise. They also underlined the necessity of consistency of guests' experiences with the brand. Interestingly, the study revealed that employees are aware of the importance of their behaviour alignment with the brand and the consistent service delivery: 'We have to align ourselves with the brand. It is uncertain which staff will encounter guests so every single member of staff, including those at back of the house, have to express the brand accurately in the same way'. ${ }^{46}$

Training programmes and IC tools were identified as the major mechanisms in internal branding. While management used the term 'internal communications', employees enumerated different tools (eg daily briefings, newsletters, notice boards and logbooks) that they regarded as giving them the relevant and essential brand information. While training was mentioned by management and employees as important to develop and reinforce employees' brand-supporting behaviour, other HR strategies (eg recruitment and reward mechanisms) were not raised. While management contended that personality was another critical factor to the recruitment of employees, it was difficult to assess whether employees' values fit with the organisation's and the brand's. To overcome 
any possibilities of recruiting the wrong people, orientation was designed for new employees as their first training programme to educate them to the organisation's mission and the brand vision. Also, there was a specified period of time before potential candidates could be classified as the employees of the brand. Management regarded rewards as a factor to enhance employee commitment to the delivery of the brand promise. No employees, however, referred to rewards as proving a guide to correct brand behaviours.

While the practice of internal branding aims to create on-brand behaviours, management believed that to ensure that employees behave accordingly, 'their head needs to accept the brand'. ${ }^{47}$ According to management, when employees identify themselves with and are committed to the brand, they will behave in ways that support the brand identity. ${ }^{27}$ The interviews with employees added brand loyalty as another important attitude. By expressing their intention to remain with the brand, employees are aware that they need to work up to the brand standards. As such, the qualitative findings suggested that ICs and training have an influence on the extent to which employees can fulfil the brand promise. The strength of the relationship is, however, mediated by the attitudes employees hold towards the brand.

To determine the mediator effects of each brand attitude, a series of mediated regression analyses were conducted as outlined by Frazier et al. ${ }^{48}$ The first step required the predictor (ie ICs and training) to have a significant relation with the outcome (brand performance). The second relationship between the hypothesised mediator and the outcome has to be found to exist. Finally, the fully mediated model between the predictor, the mediator and the outcome were calculated. To state that there is a mediational effect, the strength of the relationship between the predictor and the outcome needs to be significantly reduced. When the strength of the predictor-outcome relationship becomes nonsignificant, there is complete mediation.

Focusing first on the relationship between ICs and employees' brand performance, three hypothesised mediators (brand identification, brand commitment and brand loyalty, respectively) entered a separate series of the analysis. As Table 3 shows, the relationship of each

Table 3 Mediator effects of brand identification on the internal communications-employees' brand performance relationship

\begin{tabular}{|c|c|c|c|c|c|}
\hline $\begin{array}{l}\text { Testing steps in mediation } \\
\text { model }\end{array}$ & B & SE B & $95 \% \mathrm{Cl}$ & $\beta$ & Sig. \\
\hline \multicolumn{6}{|l|}{ Testing Step I } \\
\hline \multicolumn{6}{|l|}{ Outcome: Brand performance } \\
\hline Predictor: Internal communications & 0.615 & 0.046 & $0.525,0.704$ & 0.458 & 0.000 \\
\hline \multicolumn{6}{|l|}{ Testing Step 2} \\
\hline \multicolumn{6}{|l|}{ Outcome: Brand identification } \\
\hline Predictor: Internal communications & 0.784 & 0.045 & $0.697,0.872$ & 0.558 & 0.000 \\
\hline \multicolumn{6}{|l|}{ Testing Step 3} \\
\hline \multicolumn{6}{|l|}{ Outcome: Brand Performance } \\
\hline Mediator: Brand identification & 0.25 & 0.038 & $0.176,0.325$ & 0.262 & 0.000 \\
\hline Predictor: Internal communications & 0.418 & 0.053 & $0.314,0.523$ & 0.312 & 0.000 \\
\hline
\end{tabular}


step was statistically significant. There was, however, a significant drop of coefficients for ICs as the $z$-score of mediated effect ${ }^{49}$ is 7.84. Thus, brand identification was a significant partial mediator. In addition, about 32 per cent of the total effect of $\mathrm{IC}^{50}$ on employee performance is mediated by brand identification.

Similar to brand identification as a mediator, employees' brand commitment was not a complete mediator. Table 4 reveals that although all relationships were significant, there was a decrease in the beta-weights for ICs of step $1(B=0.615$, $p \leqslant 0.001))$ and step $3 \quad(B=0.423$, $p \leqslant 0.001)$. The $z$-score of 3.92 suggested that the drop was significant. Also, 31 per cent of the influence of ICs on employee performance was mediated by their brand commitment.

Table 5 reveals that brand loyalty is another factor mediating the IC-performance relationship. Similar to other attitudes, brand loyalty does not completely mediate the relationship. The statistically significant drop of the beta-weight of ICs ( $z-$ score $=4.55)$ supported the finding that the relationship was partially mediated by

Table 4 Mediator effects of brand commitment on the internal communications-employees' brand performance relationship

\begin{tabular}{llllll}
\hline Testing steps in mediation model & $\mathbf{B}$ & SE B & $\mathbf{9 5 \%} \mathbf{C l}$ & $\boldsymbol{\beta}$ & Sig. \\
\hline $\begin{array}{l}\text { Testing Step I } \\
\text { Outcome: Brand performance } \\
\quad \text { Predictor: Internal communications }\end{array}$ & 0.615 & 0.046 & $0.525,0.704$ & 0.458 & 0.000 \\
& & & & & \\
Testing Step 2 & & & & & \\
$\quad$ Outcome: Brand commitment & 0.759 & 0.042 & $0.677,0.842$ & 0.569 & 0.000 \\
$\quad$ Predictor: Internal communications & & & & & \\
& & & & & \\
Testing Step 3 & & & & & \\
$\quad$ Outcome: Brand performance & 0.253 & 0.040 & $0.174,0.333$ & 0.252 & 0.000 \\
$\quad \begin{array}{l}\text { Mediator: Brand commitment } \\
\text { Predictor: Internal communications }\end{array}$ & 0.423 & 0.054 & $0.317,0.529$ & 0.315 & 0.000 \\
\hline
\end{tabular}

Table 5 Mediator effects of brand loyalty on the internal communications-employees' brand performance relationship

\begin{tabular}{|c|c|c|c|c|c|}
\hline Testing steps in mediation model & B & SE B & $95 \% \mathrm{Cl}$ & $\beta$ & Sig. \\
\hline \multicolumn{6}{|l|}{ Testing Step I } \\
\hline \multicolumn{6}{|l|}{ Outcome: Brand performance } \\
\hline Predictor: Internal communications & 0.615 & 0.046 & $0.525,0.704$ & 0.458 & 0.000 \\
\hline \multicolumn{6}{|l|}{ Testing Step 2} \\
\hline \multicolumn{6}{|l|}{ Outcome: Brand loyalty } \\
\hline Predictor: Internal communications & 0.662 & 0.059 & $0.546,0.778$ & 0.392 & 0.000 \\
\hline \multicolumn{6}{|l|}{ Testing Step 3} \\
\hline \multicolumn{6}{|l|}{ Outcome: Brand performance } \\
\hline Mediator: Brand loyalty & 0.138 & 0.029 & $0.082,0.195$ & 0.174 & 0.000 \\
\hline Predictor: Internal communications & 0.523 & 0.049 & $0.428,0.619$ & 0.390 & 0.000 \\
\hline
\end{tabular}


the employees' loyalty towards the brand. The amount being mediated was approximately 15 per cent.

Three brand attitudes were entered into another mediated regression analysis with training as the predictor to determine whether the training-performance relationship was also influenced by employees' brand attitudes. Table 6 depicts that while all relationships reach statistical significance, the unstandardised beta-weight of training reduced from 0.434 in step 1 to 0.247 in step 3 . The $z$-score was 8.5 , suggesting that the drop was significant and there is a partial mediation of 43.1 per cent.

Another mediated regression analysis also suggested that the link between training and employees' brand performance is partially mediated by employees' brand commitment. As Table 7 reveals, all relations are statistically significant at $p<0.001$ level; the unstandardised coefficient for training decreases from 0.434 $(p<0.001)$ in step 1 to $0.249(p<0.001)$ in step 3 . The calculation of the $z$-score

Table 6 Mediator effects of brand identification on the training-employees ' brand performance relationship

\begin{tabular}{|c|c|c|c|c|c|}
\hline $\begin{array}{l}\text { Testing steps in mediation } \\
\text { model }\end{array}$ & B & SE $B$ & $95 \% \mathrm{Cl}$ & $\beta$ & Sig. \\
\hline \multicolumn{6}{|l|}{ Testing Step I } \\
\hline \multicolumn{6}{|l|}{ Outcome: Brand performance } \\
\hline Predictor: Internal communications & 0.434 & 0.038 & $0.359,0.508$ & 0.398 & 0.000 \\
\hline \multicolumn{6}{|l|}{ Testing Step 2} \\
\hline \multicolumn{6}{|l|}{ Outcome: Brand Identification } \\
\hline Predictor: Internal communications & 0.627 & 0.036 & $0.555,0.698$ & 0.549 & 0.000 \\
\hline \multicolumn{6}{|l|}{ Testing Step 3} \\
\hline \multicolumn{6}{|l|}{ Outcome: Brand performance } \\
\hline Mediator: Brand Identification & 0.298 & 0.038 & $0.223,0.373$ & 0.312 & 0.000 \\
\hline Predictor: Internal communications & 0.247 & 0.044 & $0.161,0.333$ & 0.226 & 0.000 \\
\hline
\end{tabular}

Table 7 Mediator effects of brand commitment on the training-employees' brand performance relationship

\begin{tabular}{llllll}
\hline Testing steps in mediation model & $\mathbf{B}$ & SE $\mathbf{B}$ & $\mathbf{9 5 \%} \mathbf{C l}$ & $\boldsymbol{\beta}$ & Sig. \\
\hline $\begin{array}{l}\text { Testing Step I } \\
\quad \text { Outcome: Brand performance } \\
\quad \text { Predictor: Internal communications }\end{array}$ & 0.434 & 0.038 & $0.359,0.508$ & 0.398 & 0.000 \\
& & & & & \\
$\begin{array}{l}\text { Testing Step 2 } \\
\quad \text { Outcome: Brand commitment }\end{array}$ & & & & & \\
$\quad$ Predictor: Internal communications & 0.605 & 0.034 & $0.528,0.672$ & 0.558 & 0.000 \\
& & & & & \\
$\begin{array}{l}\text { Testing Step 3 } \\
\quad \text { Outcome: Brand performance }\end{array}$ & & & & & \\
$\quad$ Mediator: Brand commitment & 0.305 & 0.041 & $0.225,0.386$ & 0.304 & 0.000 \\
$\quad$ Predictor: Internal communications & 0.249 & 0.044 & $0.162,0.336$ & 0.228 & 0.000 \\
\hline
\end{tabular}


of the mediated effect (2.15) supports that the drop was significant. Forty-three per cent of total amount that the influence of training has on employees' brand performance was mediated by brand commitment.

Likewise, the link between training and employees' brand performance was found to be partially mediated by their brand loyalty. According to Table 8, the relationship of each regression step is statistically significant. There is, however, a decrease of the beta-weight for training. In step 1, the unstandardised regression coefficient associated with the trainingemployee performance was 0.434 $(p<0.001)$. In step 3 , the coefficient became $0.249(p<0.001)$. The $z$-score of 4.83 indicates that there is a partial mediation; the proportion of the influence of training on employee performance being mediated was 20 per cent. Hence, the study suggests that brand attitudes that employees hold improve the relationship between ICs and their performance as well as the training-performance relationship. IC and training still exert a direct influence on the employee performance. Moreover, these tools affect the three brand attitudes as well as employees' brand performance.
Finally, the regression analysis was carried out between brand performance as a dependant variable and IC and training as independent variables. This is to directly assess their relative influences on the extent to which employees perform to match brand standards and/or expectations. As revealed in Table 9, ICs and training can predict 22.2 per cent of variance in employee performance. The ANOVA test supports their statistically significance $[\mathrm{F}(2,685)=97.72, p<0.001]$. The effect ICs has over employee performance is much stronger than training does. Although the standardised regression coefficient for training $(0.153)$ is significant at the conventional level $0.05(0.001)$, it is smaller than ICs $(0.352, p=0.000)$.

\section{DISCUSSION}

Although the 'internal branding' concept places an emphasis on employees, the literature has been largely driven by the insights from management and consultants. This study expands the existing knowledge by introducing the customerfacing employees' perspective. At the same time, it provides management with an integrated understanding to help orchestrate an internal branding campaign to

Table 8 Mediator effects of brand loyalty on the training-employees' brand performance relationship

\begin{tabular}{llllll}
\hline Testing Steps in Mediation Model & $\mathbf{B}$ & SE B & $\mathbf{9 5 \%} \mathbf{C l}$ & $\boldsymbol{\beta}$ & Sig. \\
\hline $\begin{array}{l}\text { Testing Step I } \\
\text { Outcome: Brand performance } \\
\quad \text { Predictor: Internal communications }\end{array}$ & 0.434 & 0.038 & $0.359,0.508$ & 0.398 & 0.000 \\
& & & & & \\
$\begin{array}{l}\text { Testing Step 2 } \\
\quad \text { Outcome: Brand loyalty }\end{array}$ & & & & & \\
$\quad \begin{array}{l}\text { Predictor: Internal communications } \\
\text { Testing Step 3 }\end{array}$ & 0.556 & 0.048 & $0.463,0.650$ & 0.405 & 0.000 \\
$\quad$ & & & & & \\
$\quad \begin{array}{l}\text { Outcome: Brand performance } \\
\text { Mediator: Brand loyalty }\end{array}$ & 0.157 & 0.030 & $0.099,0.216$ & 0.198 & 0.000 \\
$\quad$ Predictor: Internal communications & 0.346 & 0.041 & $0.266,0.426$ & 0.317 & 0.000 \\
\hline
\end{tabular}


Table 9 Internal communication and training influence employees' brand performance

\begin{tabular}{llllllll}
\hline Model & \multicolumn{2}{l}{$\begin{array}{l}\text { Unstandardised } \\
\text { coefficients }\end{array}$} & $\begin{array}{l}\text { Standardised } \\
\text { coefficients }\end{array}$ & $\boldsymbol{t}$ & Sig. & $\begin{array}{l}\text { Collinearity } \\
\text { statistics }\end{array}$ \\
\cline { 2 - 8 } & $\mathbf{B}$ & Std. error & Beta $(\boldsymbol{\beta})$ & & & Tolerance & VIF \\
\hline I (Constant) & 1.465 & 0.176 & & 8.318 & 0.000 & & \\
Internal communications & 0.472 & 0.063 & $\mathbf{0 . 3 5 2}$ & 7.498 & $\mathbf{0 . 0 0 0}$ & 0.515 & $1.94 \mathrm{I}$ \\
Training & 0.166 & $0.05 \mathrm{I}$ & $\mathbf{0 . 1 5 3}$ & 3.25 & 0.001 & 0.515 & $1.94 \mathrm{I}$ \\
\hline
\end{tabular}

create and reinforce on-brand behaviours. Within this case study, customer-facing employees are in agreement with their management in relation to their crucial role in living the brand by delivering on brand promise, which is also in accordance with the literature. ${ }^{3,13,14}$ They were enthusiastic about representing the brand values through maintaining what the brand has promised to its client. Not only did they perceive themselves as significant, but they also regarded back-of-the-house employees also as a key component in fulfilling the brand promise. Although those at the back of house are virtually invisible to customers, they are regarded as significant components of seamless brand promise delivery. One observation is that to ensure that employees can enact brand values to fulfil the brand promise, management have to put an effort in to translating these values into daily activities with which they can then associate.

Furthermore, the study assists management in devising the right tools that will effectively and efficiently establish the shared understanding of the right pattern of brand-supporting behaviours. The study reveals that the involvement of expertise from Marketing and HR is necessary. ${ }^{25,31}$ However, ICs appear to have a stronger effect on how employees perform their promise-keeping role than training does. One cannot deny the influence that training exerts on reinforcing the right understanding of the brand-supporting behaviours because the study shows that most of the influences that training has on employees' performance are through its effects on the employees' brand attitudes. While management can influence employees' behavioural changes to support the brand promise delivery by the practice of IC and training, the study also suggests that their performance is enhanced when they have positive brand attitudes, namely brand identification, brand commitment and brand loyalty. Yet, management can also influence their attitudes with the application of IC and training in internal branding process. ${ }^{16,18-20}$ It is, however, noted that brand loyalty has the least impact on their performance. This may be due to the nature of the hotel industry, as it is characterised by a high turnover of staff. ${ }^{51}$ Still, future research is needed to better understand the role of employee loyalty in relation to branding literature. Overall, as represented by Figure 2, management should encourage the coordination of HR and Marketing to orchestrate the consistent brand messages to leverage the influences their practices have on employees. When employees receive coherent and well-orchestrated brand messages, their understanding is constantly reinforced and in harmony with their colleagues.

Another implication from this study concerns the process of selecting the right 


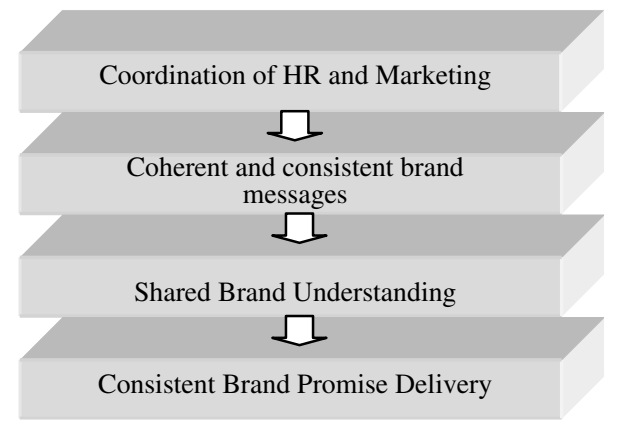

Figure 2 Coordination of HR and marketing to influence brand promise delivery

candidates. It is reasonable that employees did not mention the recruiting process as relevant to the internal branding campaign as it relies on management to be responsible for selecting and recruiting the right applicants. Although management contended that the ideal situation was to recruit the employees whose values fit with the organisation's, ${ }^{4}$ they found that it is often difficult to realise this. As a result, new employees have to pass the 'probation period' after they are employed. To support their brand understanding, the interviews revealed that all participating hotels provided their new employees with an orientation programme. In addition, when discussing the key tools to engender their brand understanding and the onbrand behaviours, employees rarely mentioned reward mechanisms and recognition schemes. The depth interviews suggested that the reward system was established to induce employees' commitment rather than attempting to directly influence their behaviours. This is an area that needs to be explored further in future studies. Management's perceptions about the importance of recruitment process and reward mechanisms and recognition schemes are, however, congruent with previous research. ${ }^{32,52}$ In summary, the study underlines the significant influences of ICs and training on employees' atti- tudes and behaviours. This suggests a significant need for the coordination of Marketing and HR activities within an organisation to establish and reinforce the alignment of employees' behaviours with the brand values.

Finally, as the corporate marketing and corporate identity literatures have recognised the involvement of the organisation's members at all levels, there is a need for future research to assess if back-ofhouse employees perceive their role differently from their front-of-the-house counterparts. Whether they perceive their role differently, there should be a research to understand whether the different perceptions necessitate different managerial mechanisms to get the brand message through to obtain person-organisation alignment.

\section{References}

(1) Balmer, J. M.T. (1998) 'Corporate identity and the advent of corporate marketing', Journal of Marketing Management, Vol. 14, No. 8, pp. 963-996.

(2) Balmer, J. M.T. and Greyser, S. A. (2006) 'Corporate marketing: Integrating corporate identity, corporate branding, corporate communications, corporate image and corporate reputation', European Journal of Marketing, Vol. 40, No. 7/8, pp. 730-741.

(3) Schultz, M. and de Chernatony, L. (2002) 'Introduction: The challenges of corporate branding', Corporate Reputation Review, Vol. 5, No. 2/3, pp. 109-113.

(4) De Chernatony, L. (2001) 'From Brand Vision to Brand Evaluation-Strategically Building and Sustaining Brands', Butterworth-Heinemann, Oxford.

(5) Tosti, T. and Stotz, D. (2001) 'Brand: Building your brand from the inside out', Marketing Management, Vol. 10, No. 2, pp. 28-33.

(6) Wittke-Kothe, C. (2001) 'Interne Markenführung-Verankerung der Markenidentität im Mitarbeiterverhalten', Deutscher Universitätsverlag $\mathrm{GmbH}$, Wiesbaden.

(7) Kelly, J. (1998) 'Paying for that old brand magic', Financial Times, 12 August, p. 8.

(8) Sharp, B. (1995) 'Brand equity and market-based assets of professional service firms', Journal of Professional Services Marketing, Vol. 13, No. 1, pp. 3-13. 
(9) Samli, A. and Frohlich, C. (1992) 'Service: The competitive edge in banking', Journal of Services Marketing, Vol. 6, No. 1, pp. 15-22.

(10) Balmer, J. and Wilkinson, A. (1991) 'Building societies: Change, strategy and corporate identity', Journal of General Management, Vol. 17, No. 2, pp. 20-33.

(11) Bharadwaj, S. G., Varadarajan, R. P. and Fahy, J. (1993) 'Sustainable competitive advantage of service industries: A conceptual model and research propositions', Journal of Marketing, Vol. 57, pp. 83-99.

(12) Day, G. S. and Wensley, R. (1988) 'Assessing advantage: A framework for diagnosing competitive superiority', Journal of Marketing, Vol. 52, pp. 1-20.

(13) Joseph, W. B. Internal marketing builds service quality', Journal of Health Care Marketing, Vol. 16, No. 1 , pp. 54-59.

(14) De Chernatony, L. and Segal-Horn, S. (2003) 'The criteria for successful services brands', European Journal of Marketing, Vol. 37, No. 7/8, pp. 1095-1118.

(15) Harris, F. and de Chernatony, L. (2001) 'Corporate branding and corporate brand performance', European Journal of Marketing, Vol. 35, No. 3/4, pp. 441.

(16) Vallaster, C. and de Chernatony, L. (2003) 'Internalisation of services brands:The role of leadership during the internal brand building process', Journal of Marketing Management, Vol. 21, pp. 181-203.

(17) Fitzgerald, T. J. (1988) 'Understanding the differences and similarities between services and products to exploit your competitive advantage', Journal of Services Marketing, Vol. 2(Winter), pp. 25-30.

(18) Vallaster, C. (2004) 'Internal brand building in multicultural organisations: A roadmap towards action research', Qualitative Market Research: An International Journal, Vol. 7, No. 2, pp. 100-113.

(19) De Chernatony, L. and Segal-Horn, S. (2001) 'Building on services' characteristics to develop successful services brands', Journal of Marketing Management, Vol. 17, pp. 645-669.

(20) Hatch, M. J. and Schultz, M. (2001) 'Are the strategic stars aligned for your corporate brand?', Harvard Business Review February, pp. 128-135.

(21) LePla, F. J. and Parker, L. M. (1999) 'Integrated Branding: Becoming Brand-Driven Through Company-Wide Action', Quorum Books, London.

(22) Meyer, J. P., Stanley, D. J., Herscovitch, L. and Topolnytsky, L. (2002) 'Affective, continuance, and normative commitment to the organisation: A meta-analysis of antecedents, correlates, and consequences', Journal of Vocational Behaviour, Vol. 61, pp. 20-52.

(23) Papasolomou, I. and Vrontis, D. (2006) 'Using internal marketing to ignite the corporate brand:
The case of the UK retail bank industry', Journal of Brand Management, Vol. 14, No. 1/2, pp. 177-195.

(24) Machtiger, B. (2004) 'Beware pitfalls that kill branding efforts', Marketing News, Vol. 38, No. 4, p. 21.

(25) Pfeffer, J. (1998) 'Seven practices of successful organisations', California Management Review, Vol. 40, No. 2, pp. 96-124.

(26) Zerbe, W., Dobni, D. and Harel, G. H. (1998) 'Promoting employee service behaviour: The role of perceptions of human resource management practices and service culture', Revue Canadienne des Sciences de l'Administration, Vol. 15, No. 2, pp. 165-179.

(27) Burmann, C. and Zeplin, S. (2005) 'Building brand commitment: A behavioural approach to internal brand management', Journal of Brand Management, Vol. 12, No. 4, pp. 279-300.

(28) Gapp, R. and Merrilees, B. (2006) 'Important factors to consider when using internal branding as a management strategy: A healthcare case study', Journal of Brand Management, Vol. 14, No. $1 / 2$, pp. 162-176.

(29) Asif, S. and Sargeant, A. (2000) 'Modelling internal communications in the financial services sector', European Journal of Marketing, Vol. 34, No. 3/4, p. 299.

(30) De Chernatony, L., Drury, S. and Segal-Horn, S (2003) 'Building a services brand: Stages, people and orientations', The Service Industries Journal, Vol. 23, No. 3, pp. 1-21.

(31) Aurand, T. W., Gorchels, L. and Bishop, T. R. (2005) 'Human resource management's role in internal branding: An opportunity for crossfunctional brand message synergy', The Journal of Product and Brand Management, Vol. 14, No. 2/3, pp. 163-169.

(32) Hoffman, J. and Mehra, S. (1999) 'Operationalising productivity improvement programs through total quality management', The International Journal of Quality \& Reliability Management, Vol. 16, No. 1, p. 72.

(33) Zeithaml, V. and Bitner, M. (2000) 'Service Marketing', McGraw-Hill, New York.

(34) Rowley, J. (2002) 'Using case studies in research', Management Research News, Vol. 25, No. 1, pp. 16-27.

(35) Amaratunga, D. and Baldry, D. (2001) 'Case study methodology as a means of theory building: Performance measurement in facilities management organisations', Work Study, Vol. 50, No. 3, pp. 95-104.

(36) Voss, C., Tsikriktsis, N. and Frohlich, M. (2002) 'Case research in operations management', International Journal of Operations and Production Management, Vol. 22, No. 2, pp. 195-219.

(37) Miles, M. B. and Huberman, A. M. (1988) 'Data management and analysis methods', in Denzin, 
N. K. and Lincoln, Y.S. (eds.) Handbook of Qualitative Research. Sage, California, pp. 428-444.

(38) Amaratunga, D., Baldry, D., Sarshar, M. and Newton, R (2002) 'Quantitative and qualitative research in the built environment: Application of mixed research approach', Work Study, Vol. 51, No. 1, pp. 17-31.

(39) Malhotra, N. and Birks, D. (2000) 'Marketing Research: An Applied Approach', European edn, Prentice-Hall, London.

(40) Mael, F. and Ashforth, B. E. (1992) 'Alumni and their alma mater: A partial test of the reformulated model of organisational identification', Journal of Organisational Behaviour, Vol. 13, pp. 103-123.

(41) Mohr, J., Fisher, R. J. and Nevin, J. R. (1996) 'Collaborative communication in interfirm relationships: Moderating effects of integration and control', Journal of Marketing, Vol. 60, No. 3, pp. 103-115.

(42) Shamir, B., Zakay, E. and Popper, M. (1998) 'Correlates of charismatic leader behaviour in military units: Subordinates' attitudes, unit characteristics, and superiors' appraisals of leader performance', Academy of Management Journal, Vol. 41, No. 4, pp. 387-409.

(43) O’Reilly III, C. and Chatman, J. (1986) 'Organisational commitment and psychological attachment: The effects of compliance, identification, and internalization on prosocial behaviour', Journal of Applied Psychology, Vol. 71, pp. 492-499.

(44) Tyagi, P. (1982) 'Perceived organisational climate and the process of salesperson motivation', Journal of Marketing Research, Vol. 19, No. 000002, pp. 240-254.

(45) Nunnally, J. (1967) 'Psychometric Methods', McGraw-Hill, New York.

(46) Business Centre Officer of Hotel P, male.

(47) Director of Food \& Beverage of Hotel S

(48) Frazier, P. A., Tix, A. P. and Barron, K. E. (2004) 'Testing moderator \& mediator effects in counselling psychology research', Journal of Counselling Psychology, Vol. 51, No. 1, pp. 115-134.

(49) Multiplying the unstandardised regression coefficient weights for Path a and Path $b$, and divided by the square root of $b^{2} s a^{2}+a^{2} s b^{2}+s a^{2} s b^{2}: a$ and $b$ are unstandardised regression coefficients and $s a$ and $s b$ are their standard errors. The result is a $z$-score of the mediated effect. When the $z$-score is greater than 1.96, the effect is significant at the 0.05 level.

(50) To describe the amount of mediation in terms of the proportion of the total effect that is mediated, $a b / c$ is applied.

(51) Duprey, R. (2006) Is E-Learning on Your Training Menu?, Retrieved 21st December, 2006 from 4Hoteliers Hospitality and Travel News website: http://www.4hoteliers.com/4hots_ fshw.php?mwi=1322.

(52) Mumby-Croft, R. and Williams, J. (2002) 'The concept of workplace marketing: A management development model for corporate and enterprise sectors', Strategic Change, Vol. 11, No. 4, pp. 205-214. 